\title{
Impact of International Remittances on Unemployment in Nigeria
}

\author{
Izuchukwu Chetachukwu Okeke \\ Department of Economics, Faculty of the Social Sciences, University of Nigeria, Nsukka
}

\begin{abstract}
Despite the implementation of stabilization measures during the present recession in Nigeria, unemployment has assumed an alarming dimension and a crisis proportion with millions of able-bodied persons who are to accept jobs at the prevailing wage rate but are unable to find placements. Unemployment can be reduced in developing countries through developmental projects but this can be achieved due to lack of finance. Sequel to that, remittance inflow serves as finance for investment purposes. This study focuses on the impact of international migrant remittances on unemployment rate in Nigeria bearing in mind that reducing the rate of unemployment is one of the macroeconomic objectives of every country. An unemployment rate model was formulated and the unit root test was first applied to the data set. The time series were stationary and the two-stage least squares (2SLS) method was used to identify the impact of remittances on unemployment rate in Nigeria. Findings reveal that international remittances affect unemployment negatively and there exists a unidirectional causality between international migrant remittances and unemployment without feedback. The study recommends that the government and other stakeholder should map out programmes that will sensitize majority of the Nigerian populace on the benefit of investing remittance money so as to become entrepreneurs, create job opportunities and become employers of labour.
\end{abstract}

Keywords: International remittances, Private Investment, Unemployment, Two Stage Least Squares.

DOI: $10.7176 / \mathrm{JESD} / 12-1-05$

Publication date: January $31^{\text {st }} 2021$

\section{Background of the Study}

Unemployment is a big problem which affects the productive capacity of a nation, hence bringing about underutilization of resources. Unemployment is a situation in which those who fall within the age bracket of labour, who are willing and able to work, are idle instead of being engaged in productive activity. By unemployment, we mean involuntary unemployment which occurs when an individual is ready to do a job at the present wage rate, but cannot find any such job. Most developing countries, including Nigeria, are passing through period of high unemployment rates despite the so-called "economic growth". Unemployment has many consequences ranging from being a threat to peace and stability; increase in crime rate; reduction in investment; migration or brain drain; waste of human resources; poverty; low standard of living, and high dependency burden. In Nigeria, many people, especially the young ones consider migration as a panacea to economic problems because of the macroeconomic instability, unemployment, corruption and poor management of resources. That is why thousands of professionals especially scientists, academics and even those in the medical fields migrate mainly to Western Europe, the United States and the Persian Gulf states. At the same time, unskilled Nigerians with little education migrate abroad to work as cleaners, security guards, e.t.c. (Chukwuone, 2007).

These migrants remit a portion of their increased income to their families back home. The money which the families receive from their migrant members abroad is known as remittance. Remittances are referred to as unrequited transfer sent by migrant workers back to relatives in their countries of origin (Juthathip, 2007). Remittances are person-to person flows, well targeted to the needs of the recipients, who are often poor, and do not typically suffer from the government problems that are associated with official aid flows. Fundamentally, remittances are personal flows from migrants to their families and friends (Dilip and Sanket, 2007). Remittances can be in form of money, assets or informal or non-monetary forms. Non- monetary forms include clothing, medicine, gifts, tools, and equipment.

According to the World Bank (2003), remittances have become a rising source of external funding for developing countries, reaching 80 billion dollars in 2002. In addition, remittances are the largest source of foreign capital in developing countries even more than Foreign Direct Investment (FDI). Remittances can form a "family welfare system" that can help to smooth consumption, alleviate liquidity constraints and provide a form of mutual assistance (Manuel, Lindsay, and Schneider, 2006). There is evidence that it alleviates poverty at household level in some countries by helping to fund schooling, reducing child labour, increasing family health and expanding durable ownership (World Bank, 2006). Remittances can improve a country's credit worthiness and thereby enhance its access to international capital markets for financing infrastructure and other development projects (Ratha, 2007).

A key factor in the interest in the issue of remittances in Nigeria is the relatively recent rise in volume. To this end, data from the World Development Indicators (WDI) show that by 2014, remittances had outpaced Foreign Direct Investment (FDI) and Official Development Assistance (ODA), being second only to oil as a foreign 
exchange earner for Nigeria as of 2015. World Bank estimates show that as of 2013, Nigerian has moved into the top ten recipients of remittances in the world and received 77 and 82 per cent of the total remittance inflow to West African countries in 2011 and 2015, respectively. The reported value was over US\$20.92 billion in 2015, excluding the informal flow, which according to Hernandez-Coss (2006), may be higher than the official inflow. International remittances enter Nigeria through formal and informal sources. The Western Union Money Transfer Mechanism is one of the major ways through which remittances enter Nigeria. Informal sources include relatives and town unions and individuals entering Nigeria form their domicile foreign countries (Chukwuone, 2007).

Despite different monetary and fiscal policy measures of the government to ameliorate the unemployment level like Medium term Strategy Paper, budget deficit targeted towards construction of basic social amenities needed to create a conducive investment climate, Subsidy Reinvestment Program (SURE-P), National Directorate of Employment (NDE) Skill Acquisition Initiative and N-POWER which is directed towards addressing youth unemployment; the rate of unemployment has continually increased over the years. Remittance serves as foreign capital needed to finance investment in a developing country like Nigeria (where there is low income and savings) which will lead to decrease in unemployment. The counter-cyclicality of remittance has made it a stable flow of income that will be invested so as to reduce the increase in the rate of unemployment.

It is against this background that this study seeks to examine the impact of international migrants' remittances on unemployment rate in Nigeria.

\section{Statement of Research Problem}

Despite the increasing size of remittances both internal and external, it seems that little or no effort has been made to investigate its impact on economic development, especially on unemployment, health, financial stabilization and human capital formation in Nigeria. United Nation (2003) report shows that poverty is prevalent in Nigeria with over $70 \%$ of people earning less than US\$1 a day.

Table 1: Remittances Over the years: 2009-2019

\begin{tabular}{|c|c|}
\hline Year & International Migrant Remittances \\
\hline 2009 & $\$ 18.3 \mathrm{bn}$ \\
\hline 2010 & $\$ 19.7 \mathrm{bn}$ \\
\hline 2011 & $\$ 20.6 \mathrm{bn}$ \\
\hline 2012 & $\$ 20.5 \mathrm{bn}$ \\
\hline 2013 & $\$ 20.9 \mathrm{bn}$ \\
\hline 2014 & $\$ 20.8 \mathrm{bn}$ \\
\hline 2015 & $\$ 21.1 \mathrm{bn}$ \\
\hline 2016 & $\$ 21.9 \mathrm{bn}$ \\
\hline 2017 & $\$ 22.0 \mathrm{bn}$ \\
\hline 2018 & $\$ 25.08 \mathrm{bn}$ \\
\hline 2019 & $\$ 23.81 \mathrm{bn}$ \\
\hline
\end{tabular}

Source: World Development Indicator (2020)

The rapid growth of remittances in Nigeria raises the question of whether these money(s) are used towards investment which will then reduce the growth rate of unemployment and thus expansion of the productive capacity of the economy. Despite the significant flow of remittances into the country in the recent past, not much is known about the impact of these remittances on unemployment rate in the country, thus this study focused on examining the impact of international migrant remittances on unemployment in Nigeria using a multiple regression approach and a causality analysis. Thus, the questions are posed as follows:

- What are the effects of international migrant remittances on the rate of unemployment in Nigeria through private domestic investment?

- What are the impacts of fiscal and monetary policy variables on unemployment in Nigeria?

\section{Objective of the Study}

The broad objective of this study is to examine the impact of international migrant remittances on unemployment rate in Nigeria. The specific objectives of the study are:

- To evaluate the effect of international migrant remittances on the rate of unemployment in Nigeria;

- To examine the impact of fiscal and monetary policy variables on unemployment in Nigeria

\section{Statement of the Hypothesis of the Study}

In carrying out this research, the following hypothesis would be tested and either accepted or rejected based on the research findings.

$\mathrm{H}_{01}$ : There is no statistically significant relationship that exist between international migrant remittances and unemployment 
$\mathrm{H}_{02}$ : The fiscal and monetary policy variables do not have any significant impact on the rate of unemployment.

\section{Significance of the Study}

This study provides information, which will benefit Nigerians and help them to make use of migrant workers' remittances. It will also help in some developmental goals such as spending remittances on investments in the following sectors of the economy: agriculture, education, health services, and also on shelter, community projects for proper development. To policy makers in the National Planning Commission, it will help in anti-unemployment policies, since remittances can help to reduce the rate of unemployment. The findings will also be significant to the private sector, foreign investors as well as the individuals, as it will inform them on the macroeconomic condition of the country. Thus, this will help in policy formulation to achieve desired growth in the economy. The findings will also be added to the already existing knowledge in the field of economics. Students and the general public who desire to carryout studies on this topic will find this research work very useful. It will also help fiscal and monetary authorities in formulating policies that will bring a sustainable growth in the economy. This study will be of great importance to the government in achieving the macroeconomic objectives of full employment and a well-sustained economic development through the formulation of relevant policies. The study will act as a source of information on the impact of remittances as an instrument for stabilizing the economy.

\section{Scope of the Study}

The scope of this study covers international migrant remittances and unemployment rate in Nigeria. This study will span over a period of 41years (1977-2018).

\section{Review of Related Literature}

\subsection{Theoretical Literature Review}

This section examines studies carried out by scholars on the topic we are investigating in order to find the missing link (if any) between the present study and those undertaken by other scholars and provide the road map to follow in the present investigation. Thus, the review was organized under the following subheadings: theoretical literature review, empirical literature, summary of literature reviewed and the justification of study.

\subsubsection{The Phillips' Curve Hypothesis}

The Phillips curve examines the relationship between the rate of unemployment and the rate of money wage changes (inflation). Known after the British economist A.W. Phillips who first identified it, it expresses an inverse relationship between the rate of unemployment and the rate of increase in money wages. Basing his analysis on data for the United Kingdom, Phillips derived the empirical relationship that when unemployment is high, the rate of increase in money wage rates is low. This is because workers are reluctant to offer their services at less than the prevailing rates when the demand for labour is low and unemployment is high so that wage rates fall very slowly. On the other hand, when unemployment is low, the rate of increase in money wage rates is high. This is because when the demand for labour is high and there are very few unemployed, we should expect employers to bid wage rates up quite rapidly. The second factor which influences this inverse relationship between money wage rate and unemployment is the nature of business activity (Jhingan, 2004). In a period of rising business activity when unemployment falls with increasing demand for labour, the employers will bid up wages. Conversely, in a period of falling business activity when demand for labour is decreasing and unemployment is rising, employers will be reluctant to grant wage increases. Rather, they will reduce wages. But workers and unions will be reluctant to accept wage cuts during such periods. Consequently, employers are forced to dismiss workers, thereby leading to high rate of unemployment. The Traditional Phillips curve model is stated as follows:

$\mathrm{gW}=\mathrm{gW}^{\mathrm{T}}-\mathrm{f}(\mathrm{UN})$

$\Delta \mathrm{UN}_{\mathrm{t}}=\alpha_{0}-\boldsymbol{\beta}_{1} \mathrm{INFt}+\boldsymbol{\beta}_{2} \mathrm{RGDPt}+\mu_{\mathrm{t}}$

Where $\mathrm{gW}$ is growth of money wages; $\mathrm{gW}^{\mathrm{T}}$ is trend rate of growth of money wages (i.e. inflation); $\mathrm{UN}$ is unemployment rate; INF is inflation rate representing change in money wages, RGDP is real gross domestic product representing the nature of business activity.

\subsubsection{Altruism hypothesis}

Altruistic behaviour has been suggested in the literature in the attempt to explain the motivation that underlies a migrant's decision to remit. Altruism is an ethical doctrine which was coined by the French philosopher, Auguste Comte (1852), as a description of the ethical doctrine he favoured. Proponents of altruism hypothesis suggest that individual family members are obligated to help each other and that this explains migrant remittance decisions (Becker 1981, 1991; Stark and Lucas, 1988; Stark 1995; Rapport and Docquier, 2006). The doctrine suggests that migrants will be willing to transmit resources to make up for the income shortfall of family members for either their consumption or investment. Altruism hypothesis suggests that a migrant will willingly sacrifice his or her own well-being or interest for the sake of the welfare of relations due to the love and concern they may have for their relation's welfare. It was Comte's belief that individuals are morally obligated to renounce self-interest and 
live for others. Pure altruism suggests that one must be benevolent and must sacrifice or forego something for the benefit of another person or persons without expecting anything in return. This sacrifice could be in the form of physical resources, time or energy. An altruistic giver does not expect to be compensated either directly or indirectly for her/his act. However, the migrant remittance decision theory of altruism in the literature has been derived from utility theory (Becker, 1981; Lucas and Stark, 1985; Stark, 1995; Osili, 2007) which suggests that by remitting, the migrant maximizes her/his expected utility. According to this theory, the decision to remit is based on the income needs of the relatives of the emigrant worker. Emigrant workers send money to their relatives in the country of origin in order to improve welfare. There is no expectation of reciprocation on the part of the migrant worker. The migrant worker remits the money because his utility is derived from that of his family members (Chami et al., 2003). In other words, the migrant worker gets satisfaction if the welfare of the family left back home improves. As a result, the motivation for the migrant worker to remit increases when his family is facing economic constraints. Remittances are therefore a form of compensatory transfers which compensate households faced by economic disruptions thus enabling them smoothen their consumption. As such remittances tend to be countercyclical; increasing during periods of economic downturns and decreasing during periods of robust economic growth. Therefore, according to this theory, remittances do not have a positive relationship with private investment since they are primarily spent on consumption activities.

\subsubsection{Neoclassical Economic Theory}

This theory of migration states that the main reason for labour migration is wage difference between two geographic locations. These wage differences are usually linked to geographic labour demand and supply. It can be said that areas with a shortage of labour but an excess of capital have a low relative wage. Labour tends to flow from low-wage areas to high-wage areas. Often, with this flow of labour comes change in the sending as well as the receiving country. Neoclassical economic theory is best used to describe transnational migration, because it is not confined by international immigration laws and similar governmental regulations.

\subsection{Empirical Literature Review}

The empirical literature related to this study has been reviewed. A sizeable volume of literature is available on the relationship between migrants' remittances and poverty or welfare. However, only few studies have been reviewed in this section on the relationship between migrants' remittances and unemployment.

Okeke, Utomi, and Ezenekwe (2019) investigated the impact of international remittances on private investment in Nigeria. Ordinary least square was used to analyze time series data sourced from World Development indicators. The result revealed that remittances increase the rate of private investment in Nigeria and that previous investment is a determinant of current investment.

Urama Nathaniel, Nwosu Emmanuel, Yuni Dennis and Aguegboh Stephen (2016) made use of propensity score matching and log linear regression model to investigate the relationship between international migrant remittances and labour supply in Nigeria. Their results show that receiving remittances negatively affect the selfemployed in agriculture, teenagers and the elderly.

Salman (2016) in his study of the influence of migrant remittances on self-employment and welfare in Nigeria used Migration and remittances household survey and reported that remittances decreased the probability of recipients being self employed by 28.4 percent.

Evans and Ramos (2015) investigated the labour supply effect of remittances in male and female household heads in Haiti, the prime international remittances recipient country in Latin American Caribbean (LAC) region relative to its GDP. Their results show that labour market response to remittances of female household heads is not as sensitive as males.

Otupuru (2014) employed a case study research method to analyze the effects of migrants' remittances on the livelihood of households in Okene local government area of Kogi State, Nigeria. The results revealed that remittances improved their livelihood through the purchase of farm implements, enrolment in tertiary education and increase in consumption patterns.

Odior (2014) analyzed the impact of remittances on the national household income in Nigeria using autoregressive distributed lag model, and found that remittances have a significant effect on the national household disposable income both in short and longrun in Nigeria.

Jongwanich (2007) who investigated the impact of workers' remittances on economic growth and poverty using descriptive statistical analysis finds out that remittances do have a significant impact on poverty reduction and have only a marginal effect on growth operation.

On the other hand, Cox-Edwards and Rodriguez-Oreggia (2006) in their study of remittances and labour supply in Mexico using the propensity score matching (PSM) found no evidence of remittances affecting labour force participation in Mexico, while Drinkwater, Levine and Lotti (2003) found that migration and the resulting remittances can have both positive and negative effects on labour supply and labour market participation decisions in the home country.

Dorantes and Pozo (2006) investigated relationship between migrants' remittances and male and female 
employment patterns and reported that remittances might defray migration related expenses and at the same time alter household labour supply. Esquivel and Huerta-Pineda (2006) investigated the effect of remittances on poverty condition among Mexican households and find out that receiving remittance reduces the household's probability of being in food-based and in capabilities-based poverty by 7.7 and 6.6 percentage points respectively. The authors concluded that these effects represent a reduction of around 36 and 23 percent in the corresponding poverty rates for a typical remittance-receiving household vis-a-vis a comparable non-remittance receiving household.

Taylor, Mora, and Adam (2005), in as study in rural Mexico, find that international remittances account for a sizeable proportion of total per capita household income in rural Mexico and that international remittances reduce both the level and depth of poverty.

In a cross-country analysis, Tabuga (2007) analyzed the relationship between international remittances and household expenditure using the two stage least squares and observed that with remittances, households allocated more to consumer goods and leisure. He finds that remittance induces household to spend more on education, housing and durable goods. He also finds that it does not induce household to spend more on goods like tobacco and alcohol and on food regularly eaten outside. Yang (2005) in his study of remittances, investment in education, human capital and entrepreneurship in Philippines using a regression analysis, reported that there is a positive impact on potentially investment related to disbursement, particularly, education and on ownership of durable goods. He also finds positive impact of remittances on education investment, that remittances increase the likelihood of being a student in Philippine household.

On the health outcomes, Hildebrandt and Mckezie (2006) examined the relationship between remittances and health care delivery using a household survey, results for Mexican case show that migrant households have lower rates of infant mortality and higher birth rates and weights. Moreover, they find evidence that migration also raises maternal health knowledge and the likelihood that the child was delivered by a doctor. On the other hand, preventive health care (breast feeding, doctor visits and vaccinations) seems to be less likely for children from migrants' households at the community level and are associated with lower infant mortality rates.

Woodruff and Zenteno (2001) in their study of the impact of remittances on health care using a household survey discovered that in Sri Lanka, the children in remittance-receiving households have higher birth weight, reflecting that remittances enable households to afford better health care.

Having reviewed the literature on the relationship between international migrant remittances and unemployment, in this study section, we have also reviewed some relevant empirical literature on the impact of remittances on labour supply because there is no previous study on the impact of remittance on unemployment. In line with this thinking, the study has reviewed little relevant literature on the factors affecting unemployment to address the objectives of this study. Despite the importance of unemployment as one of the macroeconomic objectives of any country, this area has not been explored. This paper, therefore, aims to fill this gap, and to put remittances in the spotlight, by highlighting its activities towards reducing the rate of unemployment.

\section{Research Method: Theoretical Framework}

The theoretical background of the study is rooted in Phillips Curve Hypothesis. Phillips curve is an economic concept developed by A.W. Phillips stating that inflation and unemployment have a stable and inverse relationship. The theory claims that with economic growth comes inflation, which in turn should lead to more jobs and less unemployment.

9. Model Specification: Since, there is no direct relationship between unemployment and remittances, the study employed a Two-Stage Least Squares. Two Stage Least Squares method of estimation is used to handle model with endogenous explanatory variables in a linear regression framework. An endogenous variable is a variable that have values determined or influenced by one or more independent variables in the model excluding itself. Using endogenous variables is in contradiction with the linear regression assumption of uncorrelation of variables with the error term. The general principle of Two Stage Least Squares is to use instrumental variables uncorrelated with the error term to estimate the model parameters. Instrumental variable is used in regression analysis when you have endogenous variables- variables that are influenced by other variables in the model. These instrumental variables are correlated to the endogenous variables but not with the error term of the model.

Remittances influence the level of investment in the economy, sequel to that, investment factor will then affect the changes in the level of unemployment. This is because remittances serve as foreign capital needed for investment in developing country characterised with low income and low savings. This capital when investment will bring about decrease in the rate of unemployment. Hence, the two models are stated below.

The functional and econometrics relationship between the dependent variable and the independent variables are provided in the equations below. The functional model adopted and modified the view of Urama et al. (2016). $\mathrm{PINV}=\left(\mathrm{PINV}_{-1}, \mathrm{IMR}, \mathrm{INF}, \mathrm{RGDP}, \mathrm{NX}, \mathrm{PSE}\right)$

$\mathrm{UNEMP}=(\mathrm{IMR}, \mathrm{PINV}, \mathrm{INTR}, \mathrm{INF}, \mathrm{RGDP}, \mathrm{NX}, \mathrm{PSE})$.

That is, the model expressed unemployment rate as dependent on international migrant remittances, private 
investment inflation rate, interest rate, Real Gross Domestic Product, net exports, primary school enrolment (which is a proxy for educational level).

$\mathrm{PINV}_{\mathrm{t}}=\beta_{0}+\beta_{1} \mathrm{PINV}_{\mathrm{t}-1}+\beta_{2} \mathrm{IMR}_{\mathrm{t}}+\beta_{3} \mathrm{NX}_{\mathrm{t}}+\beta_{4} \mathrm{PSE}_{\mathrm{t}}+\beta_{5} \mathrm{RGDP}_{\mathrm{t}}+\mu_{\mathrm{t}}$

$\mathrm{UNEMP}_{\mathrm{t}}=\beta_{0}+\beta_{1} \mathrm{IMR}_{\mathrm{t}}+\beta_{2} \mathrm{PINV}_{\mathrm{t}}+\beta_{3} \mathrm{RGDP}_{\mathrm{t}}+\beta_{4} \mathrm{NX}_{\mathrm{t}}+\beta_{5} \mathrm{PSE}_{\mathrm{t}}+\beta 6 \mathrm{INF}_{\mathrm{t}}+\mu$

Here, PINV in the first equation is an instrumental variable. It has a strong relationship with remittances (i.e. as remittance rises, private investment will increase in the economy), this will in turn affect UNEMP in the second model. It is expected that as remittances increase, investment will rise which will lead to decrease in the level of unemployment in the economy.

\section{Estimation Technique and Procedure}

The study conducted a stationarity test for each variable by employing the augmented Dickey-Fuller unit root and Phillip-Perron unit root tests to check the stationarity property of each variable in order to avoid spurious regression. A stationary time series is always stable, and its mean and covariance are constant over time, hence can be used for forecasting purposes. The general form of ADF is estimated by the following regression

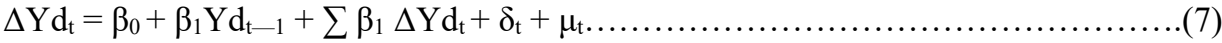

Where: $\mathrm{Yd}_{\mathrm{t}}$ is a time series

$\mathrm{t}$ is a linear time trend

$\Delta$ is the first difference operator

$\beta_{0}$ is a constant

$\mathrm{t}-1$ is optimum number of lag in the independent variables

10.1 Cointegration test: The Augmented Dickey-Fuller cointegration technique was conducted to test the existence of long run relationships amongst the variable. Essentially, in the Augmented Dickey-Fuller test, the stationarity of the residuals shows that there is an existence of long run relationships amongst the variable.

10.2 Error Correction Model: If cointegration is proven to exist, then the next step requires the construction of error correction mechanism (ECM) to model dynamic relationship. The purpose of the ECM is to indicate the speed of adjustment from the short run equilibrium to the long run equilibrium state. The greater the coefficients of the parameter, the higher the speed of adjustment of the model from the short run to the long run. The model specification with an ECM form can be formulated as follows:

$\mu_{\mathrm{t}-1}=$ UNEMP- $\beta_{0}-\beta_{1}$ IMR $-\beta_{2}$ INF- $-\beta_{3}$ RGDP $-\beta_{4} \mathrm{NX}-\beta_{5}$ PSE- $\beta_{6}$ PINV

10.3 Evaluation of Estimates

Various statistical tests have been used to evaluate the estimated results e.g. the t-test, F-test, error correction model to establish the long run linear relationship between variables in the model.

\section{Nature and Sources of Data}

Since the research is quantitative in nature, the study uses time series data from secondary sources. The data required for are sourced through library research, publications of: Central Bank of Nigeria (CBN), National Bureau of Statistics (NBS) and World Development Indicators.

\section{Data Presentation, Analysis and Discussion of Findings}

Stationarity test was conducted using two traditional unit root tests to side step spuriousness of the regression result. The traditional tests employed are Augmented Dickey-Fuller (ADF) test and Phillips-Perron (PP) test. The two tests were used to test for consistency and where conflicts exist, we choose Phillips-Perron test because PP test have been made robust to serial correlation by using the Newey-West (1987) heteroscedasticity and autocorrelation consistent covariance matrix estimator. One advantage of Phipps-Perron over the Augmented Dickey-Fuller is that PP tests are robust to general forms of Heteroskedasticity in the error term. Another advantage is that the user does not have to specify a lag length for the test regression.

The result of the unit root test conducted using the Augmented Dickey Fuller (ADF) and Phillips-Perron tests is presented in table 4.1 and 4.2 below. The series possess an intercept but no trend and the ADF test is run against the null hypothesis of non-stationarity. As a rule, once the ADF statistic is greater than the critical value at any chosen level of significance, the null hypothesis is rejected in favour of the alternate hypothesis and this implies that the data is stationary. Table 4.1 shows that all the variables are stationary at first difference using the 5\% level of significance except for private investment which is stationary at level form. The same goes with Phillips-Perron test in table 4.2. This paper concludes that all the variables used for the analysis are stationary and cannot cause spuriousity of results obtained. A time series that is integrated of order zero is the time series that admits moving average representation. This implies that the autocovariance is decaying to zero sufficiently and quickly. This is a necessary but a sufficient condition for a stationary process. Therefore, all stationary processes are $\mathrm{I}(0)$, but not all $\mathrm{I}(0)$ processes are stationary. A process is integrated to order one if taking a difference yields a stationary process. 
Table 2: Augmented Dickey-Fuller (ADF) Unit Root Test.

\begin{tabular}{|l|l|l|l|l|l|}
\hline Variable & ADF Statistic & Level of Significance & Critical Values & Order of Integration & Conclusion \\
\hline UNEMP & -5.619463 & $5 \%$ & -2.945842 & $\mathrm{I}(1)$ & Stationary \\
\hline IMR & -4.760332 & $5 \%$ & -2.943427 & $\mathrm{I}(1)$ & Stationary \\
\hline INF & -4.769208 & $5 \%$ & -2.951125 & $\mathrm{I}(1)$ & Stationary \\
\hline RGDP & -6.166795 & $5 \%$ & -2.943427 & $\mathrm{I}(1)$ & Stationary \\
\hline NX & -6.336447 & $5 \%$ & -2.945842 & $\mathrm{I}(1)$ & Stationary \\
\hline PSE & -3.919623 & $5 \%$ & -2.943427 & $\mathrm{I}(1)$ & Stationary \\
\hline PINV & -5.555001 & $5 \%$ & -2.963972 & $\mathrm{I}(0)$ & Stationary \\
\hline
\end{tabular}

Table 3: Phillips-Perron (PP) Unit Root Test.

\begin{tabular}{|l|l|l|l|}
\hline Variable & PP Statistic & PP Critical Value & Level of Integration \\
\hline PINV & -4.626095 & -2.882748 & $\mathrm{I}(0)$ \\
\hline IMR & -3.644957 & -2.882433 & $\mathrm{I}(1)$ \\
\hline INF & -4.239827 & -2.882433 & $\mathrm{I}(1)$ \\
\hline RGDP & -4.385545 & -2.882910 & $\mathrm{I}(1)$ \\
\hline UNEMP & -6.511025 & -2.954021 & $\mathrm{I}(1)$ \\
\hline NX & -8.585502 & -2.954021 & $\mathrm{I}(1)$ \\
\hline PSE & -4.182254 & -2.954021 & $\mathrm{I}(1)$ \\
\hline
\end{tabular}

Table 4: Two-Stage Least Squares Regression Result

\begin{tabular}{|c|c|c|c|c|}
\hline \multicolumn{5}{|c|}{ Dependent Variable: UNEMP } \\
\hline \multicolumn{5}{|c|}{ Method: Two-Stage Least Squares } \\
\hline \multicolumn{5}{|c|}{ Date: $12 / 24 / 20$ Time: $11: 20$} \\
\hline \multicolumn{5}{|c|}{ Sample (adjusted): 19782018} \\
\hline \multicolumn{5}{|c|}{ Included observations: 41 after adjustments } \\
\hline \multicolumn{5}{|c|}{ Instrument list: PINV C PINV(-1) IMR RGDP INTR EXCH NX } \\
\hline Variable & Coefficient & Std. Error & t-Statistic & Prob. \\
\hline $\mathrm{C}$ & 10.58914 & 10.12080 & 1.046276 & 0.3038 \\
\hline PINV & $3.48 \mathrm{E}-06$ & $4.61 \mathrm{E}-06$ & 0.755439 & 0.4559 \\
\hline IMR & $-2.18 \mathrm{E}-10$ & $2.37 \mathrm{E}-10$ & -0.923385 & 0.3632 \\
\hline RGDP & $-7.06 \mathrm{E}-06$ & $5.02 \mathrm{E}-06$ & -1.406885 & 0.1697 \\
\hline INF & -0.092213 & 0.355971 & -0.259047 & 0.7974 \\
\hline INTR & -0.028607 & 0.078856 & -0.362771 & 0.7193 \\
\hline $\mathrm{EXCH}$ & 0.056737 & 0.042513 & 1.334581 & 0.1921 \\
\hline NX & $1.61 \mathrm{E}-06$ & $1.03 \mathrm{E}-06$ & 1.565503 & 0.1280 \\
\hline \multicolumn{2}{|l|}{ R-squared } & \multicolumn{2}{|c|}{0.615788 Mean dependent var } & 11.02895 \\
\hline \multicolumn{2}{|c|}{ Adjusted R-squared } & \multicolumn{2}{|c|}{0.526139} & 6.169099 \\
\hline \multicolumn{2}{|l|}{ S.E. of regression } & \multicolumn{2}{|c|}{4.246659} & 541.0233 \\
\hline \multicolumn{2}{|l|}{ F-statistic } & \multicolumn{2}{|c|}{7.734946} & 1.344348 \\
\hline \multicolumn{2}{|l|}{ Prob(F-statistic) } & \multicolumn{2}{|c|}{ Second-Stage SSR } & 431.6881 \\
\hline
\end{tabular}

\subsection{Test for Cointegration}

The test for cointegration in indicates that the residual is stationary hence using the Augmented Dickey-Fuller test, we conclude that there exists a long run linear relationship among the variables in the model.

\subsection{Error Correction Model}

The existence of cointegration has necessitated the need for the construction of error correction mechanism so as to model the dynamic equilibrium relationship and correct short run disequilibrium. The result from the error correction model shows that the coefficient of the ECM (i.e. the lagged value of the residual) is 0.287140 . This means that the system corrects its previous period's disequilibrium at a speed of $28.71 \%$ annually. Moreover, the sign of the error correction coefficient (residual(-1)) is positive and not significant indicating the non-validity of the long run equilibrium relationship between unemployment and the explanatory variables as proposed by Neoclassical theory of labour migration who says that development will occur in the long run, hence there would not be need for labour migration. 


\subsection{Evaluation of Research Hypothesis}

Evaluation of research hypotheses posed by the study suggests that:

$\mathrm{H}_{01}$ : There is no statistically significant relationship that exists between international migrant remittances and unemployment.

From table 4, the sign of the coefficient of international migrant remittances is negative which conforms to a priori expectation that says that the higher the international migrant remittances, the more funds will be available for investment purposes, which in turn implies that the rate of unemployment will be decreased. The result also show that international migrant remittances is not statistically significantly different from zero at 5\% level, hence conforming with the findings of other researchers like Urama et al (2015) and Onah (2010). It is clear from the coefficient of international migrant remittances that a percentage $(1 \%)$ increase in international migrant remittances will lead to $21 \%$ decrease in the rate of unemployment.

$\mathrm{H}_{02}$ : The fiscal and monetary policy variables do not have any significant impact on the rate of unemployment.

The sign of the coefficient of inflation rate is negative and conforms to a priori expectation. According to Philips Curve Hypothesis, the higher the inflation rate, the lower the rate of unemployment and vice versa. The result shows that inflation rate is not statistically significant but is still an indispensable variable in the determination of the level of unemployment due to its conformity to a priori expectation. A unit increase in inflation rate will lead to $9 \%$ decrease in the rate of unemployment in Nigeria's economy, ceteris paribus.

\section{DISCUSSION OF FINDINGS}

The coefficient of Real Gross Domestic Product is negative and conforms to a priori expectation. Though statistically insignificant, the coefficient suggests that a unit increase in Real Gross Domestic Product will lead to $70 \%$ decrease in the rate of unemployment in Nigeria since Real Gross Domestic Product measures the productive sector of the economy. The sign of the coefficient of net exports is positive and does not conform to a priori expectation. It is expected that net exports rise (which that Nigeria's productive base is expanding), that unemployment rate will be decreasing since more people will be engaged in those sectors that are expanding. The result also shows that net exports in Nigeria is not statistically significantly different from zero which means that it is not an indispensable variable in the determination of the rate of unemployment in Nigeria. Its coefficient is positive which suggests that a percentage increase in net exports will lead to $16 \%$ increase in the rate of unemployment.

Furthermore, the sign of the coefficient of private investment is positive and does not conform to a priori expectation. It is expected that the higher the level of investment by private individuals, the lower the rate of unemployment since the Nigeria's economy has embarked upon the private sector-led growth. The result indicates that a unit increase in private investment will lead to $58 \%$ increase in the rate of unemployment though it's statistically insignificant.

\section{Summary of Findings}

Findings crystallized from this study include the following:

1. International migrant remittances decrease the rate of unemployment in Nigeria.

2. Net exports contribute positively and significantly to the increase in the rate of unemployment.

\section{Conclusion and Recommendations}

The study examined the impact of international migrants' remittances on unemployment in Nigerian economy and shows that international migrants' remittances decrease the rate of unemployment. Thus, the study asserts that migrants should use part of their earnings to set up businesses in their home country, hence become an entrepreneur and an employer of labour. Youth in households receiving remittances should establish their own businesses. The following policy recommendations are made on the basis of the findings of the study:

- Enlightenment campaigns directed at recipients of remittances regarding the benefit of investing remittance money in small and medium scale entreprises be encouraged rather than using the money as a substitute for labour income.

- Policies that will encourage the flow of remittances into Nigeria be implemented like the reduction in transaction cost in Sub-Saharan African countries especially Nigeria.

- Fiscal and monetary policies should be targeted to activities with the greatest employment creating. Cheap credit should be given to agricultural activities and other productive activities that have high employment elasticity.

- Government expenditure should be directed towards activities that have a multiplier-effect on domestic production.

- It is necessary that government should implement policies that would significantly reduce the dependence of the industrial sector and the entire economy on imports.

- Government should adjust the pattern of taxation and other fiscal incentives in favour of productive 
activities which are likely to generate increased employment. Investment tax credits should be given to plantation agriculture, agro-based industries and other industrial activities using local raw materials.

\section{REFERENCES}

Becker, G.S. (1982). Treatise on the Family. Cambridge: Harvard University Press, Enlarged edition, 1991.

Becker, G.S. (1992). Habits, Addiction, and Tradition. Kyklos, 327-345. Retrieved online from www.researchgate.com on October, 2020.

Chami, R., Fullenkamp, C. and Jahjah, S. (2003). Are immigrants' remittances flows a source of capital for development? IMF Working Paper 01/189, International Monetary Fund. Washington Dc: IMF.

Chukwuone, N. (2007) "Analysis of impact of Remittances on poverty and inequality in Nigeria”, PEP Research Network General Meeting, www.peporg.

National communities. Economic Geography 74(1). 26-44.

Dorantes, A. C., and Pozo, S. (2006). Migrants' remittances and Male and Female Employment Patterns. American Economic Review 96(2), 222-226.

Esquivel, G., and Huerta-Pinida, A. (2006). Inter-American Development Bank, Remittances and Poverty in Mexico: A Propensity Score Matching Approach, (IADB), September. Available online: researchgate.com

Esquivel, G. and Huerta-Pinida, A (2006), Inter-American Development Bank,

Remittances and Poverty in Mexico: A Propensity Score Matching Approach, (IADB), September.

Gane, M. (2006). Auguste Comte's Sociological Theory and Gender in Hayek F.A. (1952). The Counter Revolution of Science: Studies in the Abuse of Reason. Retrieved online from www.library.oapen.org.

Hernandez, M. A. (2015). Estimation of Average Treatment Effects. A Training Manual on Applied Microeconometrics. AGRODEP Training Manual.

Hiderbrandt, N. and Meknezie, H. (2005). The Effects of Migration on Child Health in Mexico. Economic Journal of the Latin American and Caribbean Economic Association 6, 257-289.

IMF (2005) World Economic Outlook: International Monetary Fund, April 2005, Washington, DC.

Ilahi, N. and Jafarey, S (1999), Guest workers Migration, Remittances, and the Extended Family: Evidence from Pakistan, Journal of Development Economics, Volume 58, 485-512.

Jhingan, M.L. (2010). Macroeconomic Theory. Vrinda Publications Limited: Delhi, India.

Jongwanich, J. (2007). Workers' Remittances, Economic Growth and Poverty in Developing Asia and the Pacific Countries." UNESCAP Working Paper WP/07/01, United Nations.

Juthathip, C. (2007). Workers' Remittances, Economic growth and Poverty in Developing Asia and Pacific countries. UNESCAP Working Paper, WP/07/01. Helsinki: UNESCAP.

Lotti, E., Levine, P., and Drinkwater, S. (2006). Labour Market and Investment Effects of Remittances. Retrieved online from www.researchgate.org. on November 2, 2020.

Manuel, O., Lindsay, B., and Schnieder, J. (2006) "Gender Specific Determinants of Remittances: Differences in Structure and Motivation. World Bank Gender and Development Group, PREM

Massey, D.S., Arango, J, Hugo, G. Kouaouci, A. Pellegrino A. and Taylor, J.E. (1993), Theories of International Migration: Review and Appraisal.Stark, O. (1991) The Migration of Labor Cambridge: Basil Black well.

Odior, E.S. (2014). Remittances and the national household disposable income in Nigeria (1980-2025): Dynamic forecasting approach. British Journal of Economics, Management and Trade, 4(9), 1335-1355.

Okeke, I.C., Utomi, F.I., \& Ezenekwe, U. (2019). Impact of International remittances on Private Investments in Nigeria. Saudi Journal of Economics and Finance. DOI: 10.21276/sjef.2019.3.4.2.

Orozco, M., Lowell, L., and Schneider (2006). Gender-Specific Determinants of Remittances. Differences in Structure and Motivation. Institute for the study of International Migration, Georgetown University, Washington DC.

Osili, Una (2007). Remittances and Savings from International Migration: Theory and evidence using a matched sample. Journal of Development Economics 2007, vol. 83, Issue 2, 446-465.

Otupuru, O.A. (2014). The Effects of Migrants' remittance on the livelihood of households in Okene Local government area, Kogi State, Nigeria. Unpublished Thesis. Submitted to the School of Postgraduate Studies, Ahmadu Bello University, Zaria, Nigeria.

Rapport, H., and Docquier, F. (2005) The Economics of migrants 'remittances, IZA Discussion Paper, 1531, March. Available online: www.researchgate.com

Ratha, D. (2003). Workers' remittances: An important and stable source of external development finance. In Global Development Finance: Striving for stability in development finance, 157-175. Washington DC: World Bank Development Finance.

Ratha, D. (2005). Workers' remittances, an important and stable source of external development finance. World Bank Development Finance. Available online: www.iom.com

Ratha, D. (2007). Leveraging Remittances for Development, Policy Brief, Migration Policy Institute. Washington DC: World Bank. 
Stark, O., and Taylor, J. E. (1989). Relative Deprivation and International Migration. Demography 26, 1-14.

Stark, O. (1991). The Migration of Labor. Cambridge: Basil Black well Publishers.

United Nations (2003). World Youth Report. Retrieved online from www.un.org. on December 1, 2020.

Urama, N., Nwosu, E.O. Yunni, D., and Aguegboh, S. (2016). International Migrant Remittances and Labour Supply in Nigeria. International Migration, Vol. 54(4).

Tabuga, A. (2007). International Remittances and Household Expenditure. PIDS Discussion Paper Series $2007-$ 18.

Taylor, J.E., Mora, J. and Adams, R., (2005). Remittances Inequality and Poverty. Evidence from Rural Mexico. Mimeo: University of California. Available online: www.iom.com

Taylor, J. E., Mora, J., Adam, R., and Lope, Fieldsman (2005). Remittances, inequality and poverty. Evidence from Rural Mexico, Mimeo, and University of California. Available online: www.iom.com

Woodruff, C., and Zeneto, B. (2001). Remittances and Micro Enterprises in Mexico, UCSD Graduate School of International Relations and Pacific Studies Working Paper, University of California.

World Bank (1990). Poverty in Latin American: The Impact of Depression. Washington Dc. Available online: www.iom.com

World Bank (2004). Global Development Finance: Striving for Stability in Development finance. Washington DC. World Bank Development Finance.

World Bank (2004). Global Development Financial 2004 Harnessing Cyclical Gains for Development. Washington DC: World Bank Development finance.

World Bank (2003). Global Development Finance: Striving for Stability in Development finance. Washington DC. World Bank Development Finance.

World Bank (2020). World development Indicators. Washington Dc. Available online: www.worldbank.org

Yang D, and Choi, H. (2007). "Are Remittances Insurance? Evidence from Rainfall Shocks in the Philippines" World Bank Economic Review 4(2), 2, Working paper 19-248.

Yang, D. (2005). International Migration, Human Capital and Entrepreneurship:Evidence From Philippines Migrants' Exchange Rate Shocks Mimeo:University of Michigan.

Yang, D. and Martinez, C. (2005). Remittances and Poverty in Migrants' Home Area: Evidence from the Philippines. World Bank International Migration and Development Research Group. 